\title{
An Assessment of the Radiological Releases from the NuMI Facility during MINOS and NOvA Operations
}

\author{
Mike Martens \\ February 20, 2007
}

Abstract: This report makes projections of the radiological releases from the NuMI facility during operations for the MINOS and NOvA experiments. It includes an estimate of the radionuclide levels released into the atmosphere and the estimated tritium and sodium-22 concentrations in the NuMI sump water and Fermilab pond system. The analysis was performed for NuMI operations with a beam power on target increased from the present $400 \mathrm{~kW}$ design up to a possible $1500 \mathrm{~kW}$ with future upgrades. The total number of protons on target was assumed to be $18 \times 10^{20}$ after the completion of MINOS and $78 \times 10^{20}$ after the completion of NOVA.

\section{Table of Contents}

An Assessment of the Radiological Releases from the NuMI Facility during MINOS and

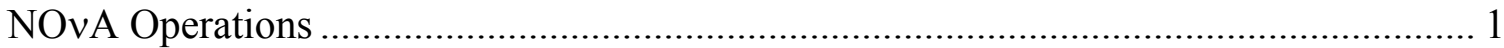

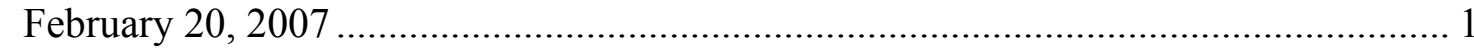

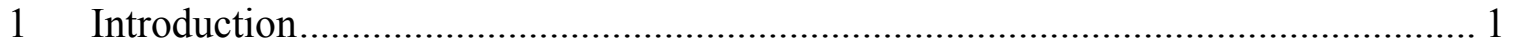

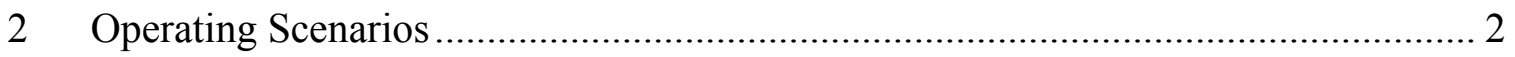

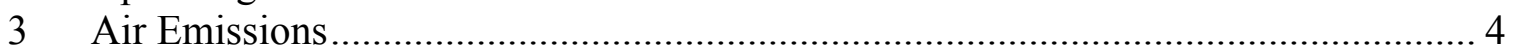

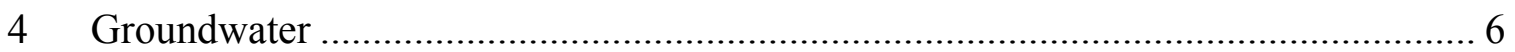

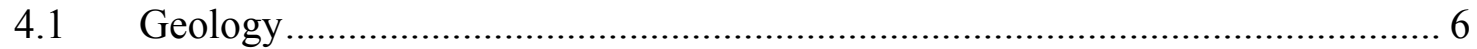

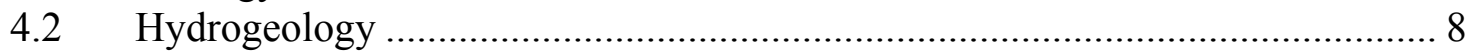

4.3 Groundwater Protection ...................................................................... 10

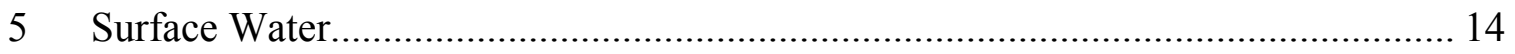

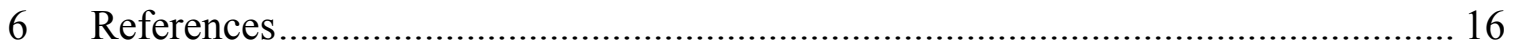

\section{Introduction}

Radiological issues are an important component in the environmental assessment of the NuMI facility during operations for the MINOS and NOvA ${ }^{1}$ experiments. This report makes projections of the radiological releases from the NuMI facility during operations for the MINOS and NOvA experiments. It includes an estimate of the radionuclide levels

\footnotetext{
${ }^{1}$ MINOS is an acronym for Main Injector Neutrino Oscillation Search. NOvA is an acronym for Neutrino Off-axis $v_{\mathrm{e}}$ Appearance 
released into the atmosphere and the estimated tritium and sodium- 22 concentrations in the NuMI sump water and Fermilab pond system.

The NuMI facility has been in operation for the MINOS experiment since the spring of 2005. As designed, the NuMI facility is capable of operating at up to 400 kilowatts (kW) of beam power delivered on target. With upgrades to the Fermilab accelerators, the NuMI facility would be capable of operating for the NOvA experiment with an increased beam power of up to 1.5 megawatts (MW).

The levels of radiological releases from the NuMI facility can depend on the average beam power on target, the integrated number of protons delivered to the NuMI target, and the time since operations (because of the half-lives of the radionuclides.) In the next section we document the operating scenario used to estimate the level of radionuclide releases. Later sections discuss the estimates for radiological emissions into the air and water.

\section{Operating Scenarios}

The NuMI beamline was commissioned in March 2005 and has been providing neutrinos for the MINOS experiment during the past two years. During this time there have been about 75 weeks of beam operations and about $2.5 \times 10^{20}$ protons delivered to the NuMI target [1]. This is a long term average of about $130 \mathrm{~kW}$ of beam power delivered to the NuMI target while operating.

As designed the NuMI facility is capable of operating at $400 \mathrm{~kW}$ of beam power delivered to the target [2]. Future upgrades to the NuMI beamline for the NOvA experiment may increase the beamline capability up to $1500 \mathrm{~kW}$ and a total of up to $8 \times 10^{21}$ protons might have been delivered to the beamline near the end of operations for NOvA. This increase is a factor of almost 4 in the beam power and a factor of 30 in the total number of protons delivered to NuMI beamline.

To project the impact these increases will have on the radiological releases we parameterizes the operations of the NuMI beamline as summarized in Table 1. This is consistent with operations for two years at $100 \mathrm{~kW}$ beam power followed by four years at $400 \mathrm{~kW}$ beam power and then six years at $1 \mathrm{MW}$ of beam power assuming a $60 \%$ accelerator uptime.

\begin{tabular}{|l|c|l|l|c|}
\hline & $\begin{array}{l}\text { Average Power } \\
\text { (Yearly Average) }\end{array}$ & $\begin{array}{l}\text { Years of } \\
\text { Operations }\end{array}$ & $\begin{array}{l}\text { Protons } \\
\text { on Target }\end{array}$ & $\begin{array}{l}\text { Accumulated } \\
\text { Protons on Target }\end{array}$ \\
\hline Previous & $100 \mathrm{~kW}$ & $2005-2006$ & $2 \times 10^{20}$ & $2 \times 10^{20}$ \\
\hline
\end{tabular}




\begin{tabular}{|l|l|l|l|l|}
\hline $\begin{array}{l}\text { MINOS } \\
\text { Operations }\end{array}$ & & $(2$ years $)$ & & \\
\hline $\begin{array}{l}\text { Future } \\
\text { MINOS } \\
\text { Operations }\end{array}$ & $400 \mathrm{~kW}$ & $\begin{array}{l}2007-2010 \\
(4 \text { years })\end{array}$ & $16 \times 10^{20}$ & $18 \times 10^{20}$ \\
\hline $\begin{array}{l}\text { NOvA } \\
\text { Operations }\end{array}$ & $1.0 \mathrm{MW}$ & $\begin{array}{l}2011-2017 \\
(6 \text { years })\end{array}$ & $60 \times 10^{20}$ & $78 \times 10^{20}$ \\
\hline
\end{tabular}

Table 1: NuMI operating scenario used for the projections in this report.

For tritium and sodium-22 in particular, the lifetimes of the isotopes are important when calculating the concentrations of radionuclide. For these we define an "effective" integrated protons on target which includes the effect of the lifetime.

$\operatorname{POT}_{\text {eff }}(\mathrm{T})=\int_{0}^{\mathrm{T}} \mathrm{P}(\mathrm{t}) \mathrm{e}^{-(\mathrm{T}-\mathrm{t}) / \tau_{1 / 2}} \mathrm{dt}$

In this equation $\mathrm{P}(\mathrm{t})$ is the rate of proton delivery at time $t$, and $\tau_{1 / 2}$ is the decay constant. The time $\mathrm{t}=0$ is the start of the NuMI operations, and the time $\mathrm{T}$ is the time at which the $\mathrm{POT}_{\text {eff }}$ is calculated. For tritium the half life is 12.3 years and for sodium-22 the half life is 2.6 years. Using these half lives with the operating scenario shown in Table 1, the $\mathrm{POT}_{\text {eff }}(\mathrm{T})$ is plotted in Figure 2.1.

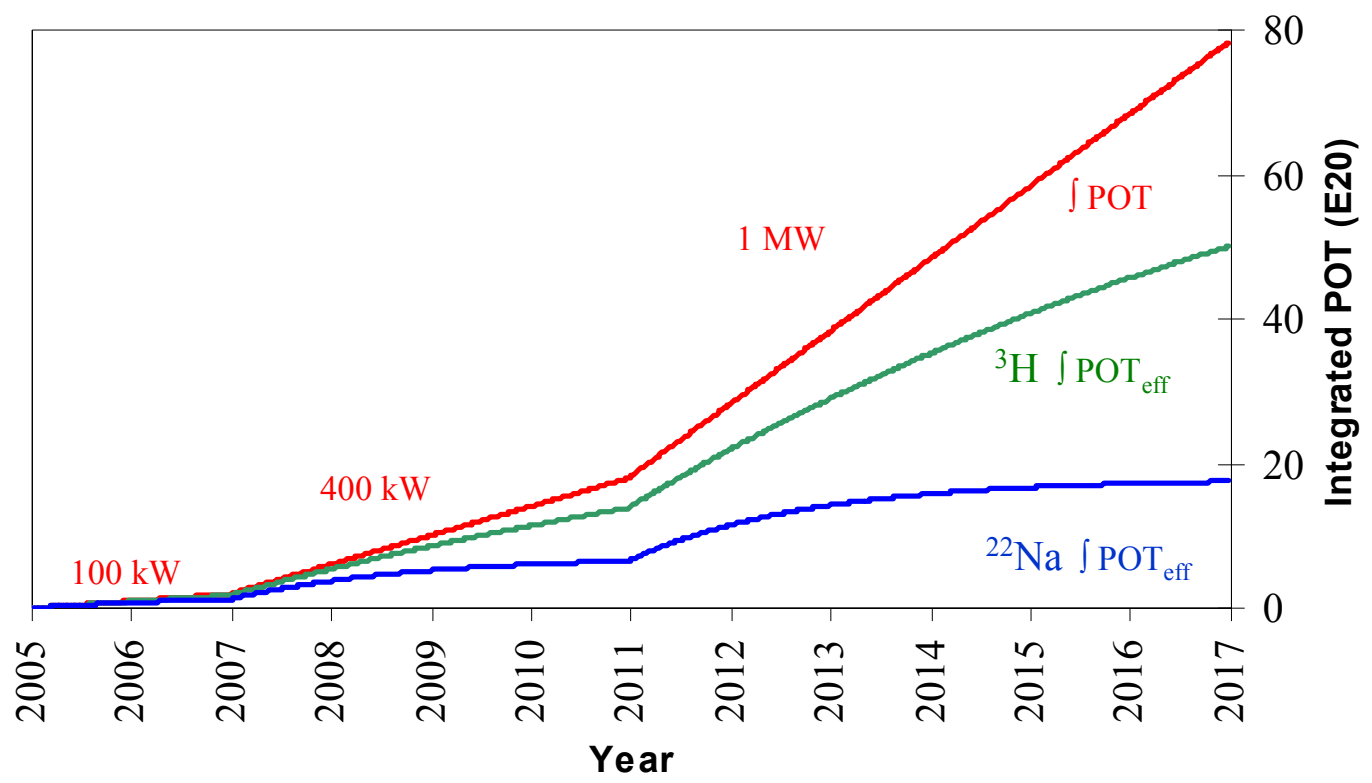


Figure 2.1: Plot of the Effective Protons on Target $\left(\mathrm{POT}_{\text {eff }}\right)$ for the operating scenario shown in Table 1.

\section{Air Emissions}

The NuMI facility (including the carrier tunnel, target hall, decay pipe passage, and absorber region) is equipped with air handling and circulation units. The airborne radionuclides produced in the NuMI facility are released into the atmosphere through vent stacks to the surface of the Fermilab site. Environmental emissions are limited by minimizing the ventilation of the tunnels during operations and by allowing sufficient time for decay and by ventilating the airborne radioactivity after a beam shutdown and prior to any personnel access.

The airborne emissions consist of short-lived gaseous radionuclides produced as an unavoidable result of proton interactions with targets. Air from the ventilation stacks is monitored for radionuclide emissions on a regular basis. The principal radionuclides typically measured to be present include carbon-11, oxygen-15, nitrogen-13, and argon41 (half-lives from 2 minutes to 1.8 hours). The most important radionuclide of concern is carbon- 11 which has a half life of 20.5 minutes.

The radionuclide emissions to the atmosphere from the NuMI beamline have been estimated by scaling the current radionuclide measurements by the ratio of beam power [4]. Operating NuMI at $400 \mathrm{~kW}$ of beam power would result in an estimated maximum release of 50 Curies of radionuclides per year, which translates to an estimated annual dose of approximately 0.2 microSieverts $(0.02 \mathrm{mrem})$ to a member of the public.

Operating the NuMI beamline under NOvA operating conditions would increase the level of radionuclide emissions to the atmosphere. One component of these emissions would continue to be short-lived gaseous emissions produced as an unavoidable result of proton interactions with targets. The total amount of such radioisotopes that would be released from the NuMI area during the NOvA experiment has been estimated based on extrapolations from measurements conducted in the course of current operations of the NuMI beamline [4]. At the maximum beam intensity with which the NOvA experiment would operate, a maximum of $1.5 \mathrm{MW}$ of beam power, the maximum release would be 150 Curies of radionuclides per year and the estimated annual dose rate equivalent would be 0.60 microSieverts $(0.06 \mathrm{mrem})$ at the Fermilab site boundary. These results are summarized in Table 2.

Tritium is another radionuclide which is produced as a by-product of NuMI operations. Some of the tritium produced by NuMI enters the atmosphere as tritiated water vapor via three mechanisms: 1) ventilation of air from the NuMI facility, 2) evaporation of tritiated water from the Central Utility Building (CUB), and 3) evaporation from the Fermilab Industrial Cooling Water (ICW) pond system. 
The maximum airborne tritium emission from the combination of these three mechanisms has been estimated for MINOS operating conditions of $400 \mathrm{~kW}$ beam power [4]. The estimated release is 20 Curies of tritium in a year which translates to an estimated annual dose to a member of the public of less than 0.002 microSieverts $(0.0002 \mathrm{mrem})$. This conservative estimate assumes that the entire amount of tritiated water becomes airborne vapor. In fact, some of the tritiated water is collected in a condensate form and removed from the NuMI facility before it can become airborne.

The maximum release of tritiated water vapor from all three mechanisms would be 80 Curies in one year under NOvA operating conditions of $1.5 \mathrm{MW}$ beam power. This would result in the estimated annual dose rate equivalent would be 0.008 microSieverts $(0.0008 \mathrm{mrem})$ at the Fermilab site boundary. These results are summarized in Table 2.

In addition to the NuMI facility, there are contributions to the release of radioactive air emissions from the rest of the Fermilab accelerators. In the 2005 calendar year operations of the Fermilab accelerators, excluding NuMI, released 30 Curies of air emissions in one year. Most of the air emissions were a result of pbar production which will not be done during the NOvA operations, so the air releases from other Fermilab accelerators will be less.

The estimates for radioactive air emissions from Fermilab during NuMI operations for the MINOS and NOvA experiments are summarized in Table 2. Totaling the estimates gives a maximum of 100 Curies per year of radioactive air emissions during MINOS operations. The total releases contribute less than 0.4 microSieverts $(0.04 \mathrm{mrem})$ per year to the site boundary dose. Estimates for the total radionuclide air emissions from all Fermilab sources under NOvA operating conditions have determined that the emissions would increase from 100 Curies in a year to 260 Curies in a year and would increase the maximum dose at the site boundary from 0.4 microSieverts $(0.04 \mathrm{mrem})$ in a year to 0.8 microSieverts $(0.08 \mathrm{mrem})$ in a year.

These estimates have demonstrated that operating NuMI at $400 \mathrm{~kW}$ beam power for the MINOS experiment or at 1.5 MW for the NOvA experiment does not cause Fermilab to approach either the NESHAP limit of 2,000 Curies per year of radioactive air emissions [3] or the 40 CFR 61 requirement [5] that the dose to any member of the public remain less than 100 microSieverts $(10 \mathrm{mrem})$ in any given year.

No revisions would be necessary to the laboratory's permits or monitoring methodologies for operation of NuMI for the NOvA experiment. In the event that radionuclide air emissions would be higher than expected, Fermilab would take measures to mitigate the release of radionuclides to keep the levels below regulatory limits. 
Table 2: Maximum release of radionuclide air emissions and maximum dose at the Fermilab site boundary during the running of NuMI facility under operating conditions for the MINOS and NOvA experiments.

\begin{tabular}{|l|c|c|c|c|}
\hline & \multicolumn{2}{|c|}{ MINOS operations } & \multicolumn{2}{c|}{ NOvA operations } \\
\hline $\begin{array}{l}\text { Source of Radionuclide } \\
\text { Air Emissions }\end{array}$ & $\begin{array}{c}\text { Maximum } \\
\text { Release } \\
\text { (Curies/yr) }\end{array}$ & $\begin{array}{c}\text { Maximum } \\
\text { Dose at Site } \\
\text { Boundary } \\
\text { (mrem/yr) }\end{array}$ & $\begin{array}{c}\text { Maximum } \\
\text { Release } \\
\text { (Curies/yr) }\end{array}$ & $\begin{array}{c}\text { Maximum } \\
\text { Dose at Site } \\
\text { Boundary } \\
\text { (mrem/yr) }\end{array}$ \\
\hline $\begin{array}{l}\text { Fermilab Accelerators } \\
\text { (Excluding NuMI) }\end{array}$ & 30 & 0.02 & 30 & 0.02 \\
\hline $\begin{array}{l}\text { NuMI Air Ventilation } \\
\text { (Short Lived Radionuclides) }\end{array}$ & 50 & 0.02 & 150 & 0.06 \\
\hline $\begin{array}{l}\text { NuMI Air Ventilation } \\
\text { (Tritium) }\end{array}$ & 20 & 0.0002 & 80 & 0.0008 \\
\hline Fermilab Site Wide Total & $\mathbf{1 0 0}$ & $\mathbf{0 . 0 4}$ & $\mathbf{2 6 0}$ & $\mathbf{0 . 0 8}$ \\
\hline
\end{tabular}

\section{Groundwater}

\subsection{Geology}

The Fermilab NuMI tunnel resides within three major geologic units: Quaternary (Glacial Till), Silurian, and Upper Ordovician. The subsurface characteristics in the vicinity of the NuMI tunnel on the Fermilab site have been documented in a number of reports $[6,7,8$, $9,10]$. Figure 4.1 shows a view of the major geological layers beneath the Fermilab surface. 


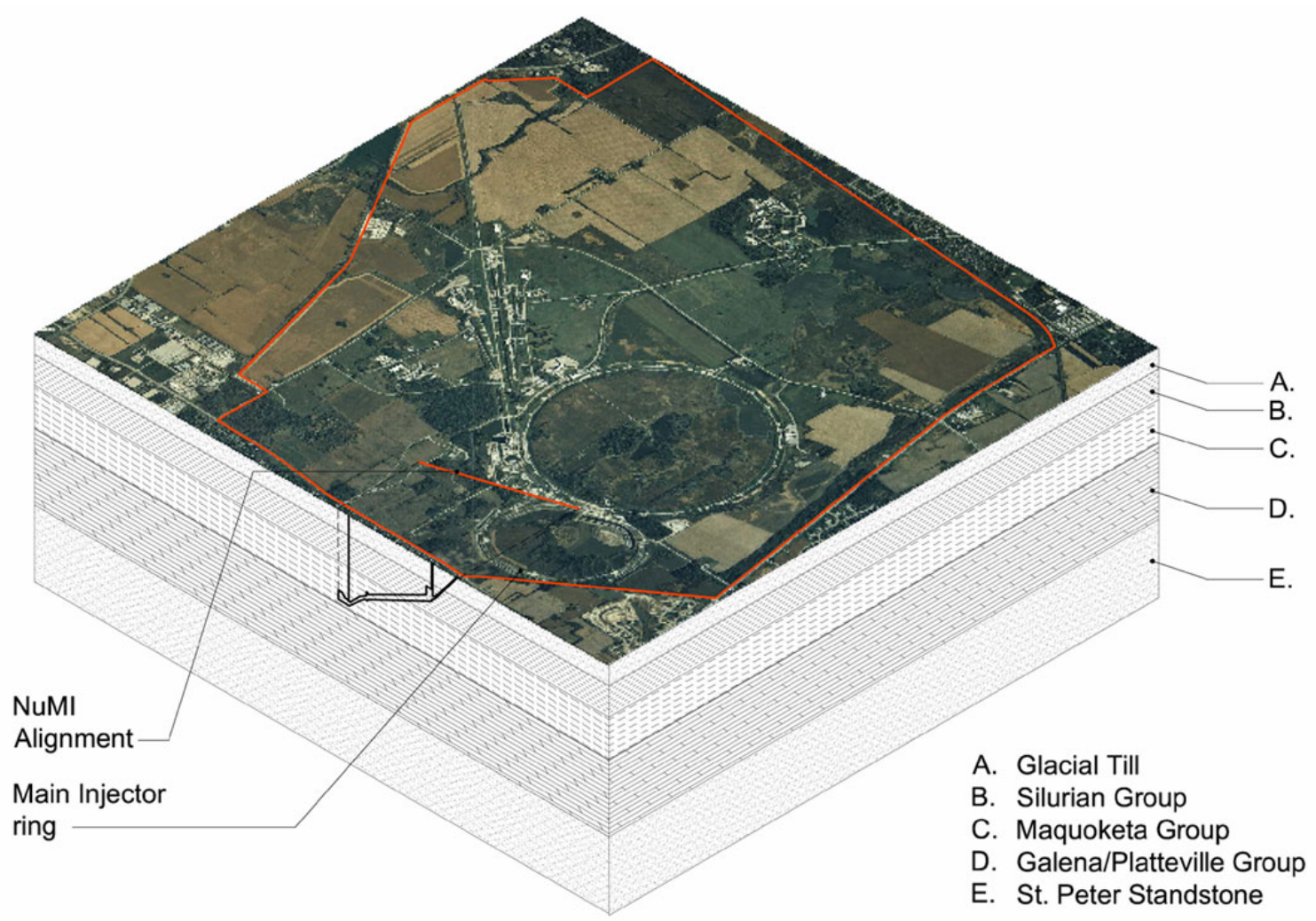

Figure 4.1: View of the Fermilab site showing the underlying geological layers. The NuMI tunnel exists in the Glacial Till, Silurian Group, and Maquoketa Group, but does not extend into the Galena/Platteville Group or the St. Peter Sandstone.

The upper geology at Fermilab consists of glacial deposits (Glacial Till) from the Wisconsin Episode of glaciation overlying bedrock of Silurian-age dolomite. Glacial Till starts at ground level [approximately 740' above mean sea level (MSL)] and goes to approximately 660 ' MSL, with variances on the order of 80 ' at most. The glacial deposits are predominantly subglacial and ice-marginal deposits, mainly fine to medium grained, massive, and are composed of a silty clay matrix with varied amounts of non- to poorlysorted, coarse gravel. The glacial deposits vary in thickness from 18 to 30 meters (60 to 100 feet) across the Lab. There are some localized, sorted sand and gravel lenses within the deposits, but none that appear to be continuous layers. The lowest deposition sequence, which is generally less than 10 feet thick, can contain sorted sand and gravel.

Below the Glacial Till is the Silurian Group of rock formations. The fractured rock in this region consists of dolostones (dolomite and limestone) with some shale. Of these, the Silurian-age dolomite extends between about 615' MSL and 400' feet MSL. The Silurian Group includes the Joliet, Kankakee, Elwood, and Wilhelmi formations. The fractures allow rapid water transport into unlined tunnels or wells. The interface region between the Glacial Till and Dolomitic Rock is an extremely variable region. This region is not considered stable for tunnel construction and thus the portion of the NuMI tunnel in this region is lined. 
The Upper Ordovician System underlies the Silurian Group and contains the Maquoketa Group (shale), the Galena/Platteville Group (Dolomite) and the St. Peter Sandstone. Regional references indicate that the Maquoketa Group shale, in combination with the upper Galena-Platteville dolomite, functions as a confining layer for the underlying Cambrian-Ordovician sandstone aquifer. The NuMI tunnel exists in the Glacial Till, Silurian Group, and Maquoketa Group. The tunnel does not extend into the Galena/Platteville Group or the St. Peter Sandstone except for an approximately 18' deep sump pit in the Galena/Platteville Group near the bottom of the NuMI tunnel.

\subsection{Hydrogeology}

Groundwater flow in the glacial deposits is generally downward and slow. Water moving through the glacial deposits recharges the underlying Silurian Dolomite aquifer. The water table fluctuates seasonally between $1.5-4.6 \mathrm{~m}$ ( 5 and 15 feet) below the ground surface.

The pitch to the NuMI tunnel causes it to traverse several different geological media, including the Silurian Dolomite. The Illinois Environmental Protection Agency (IEPA) has classified the Silurian Dolomite as a Class I groundwater aquifer. The direction of natural groundwater flow in the upper dolomite aquifer is generally toward the south/southeast. Local flow is heavily influenced, however, by the continual pumping and dewatering of the NuMI tunnel. Nearby groundwater flows towards and into the NuMI tunnel.

Below the Silurian Bedrock is the Ordovician-age Maquoketa Shale Group which serves as a low permeability aquitard that confines deeper aquifers and as a barrier to groundwater flow between the overlying dolomite and deeper aquifers. Water productivity decreases with increasing depth across the shale.

Sections of the NuMI beamline that produce radioactivity during operations are located within the Silurian Dolomite and Maquoketa Shale. Since the Silurian Dolomite is Class I aquifer understanding the hydrogeology of this region is important.

The hydrogeology of the Fermilab site along with the NuMI tunnel construction ensures that groundwater in the vicinity of the NuMI facility would continuously flow into the NuMI tunnel. Several hydrogeologic analyses have provided models of the groundwater flow within the Silurian Dolomite and Maquoketa Shale [8, 9, 10]. The models demonstrate that groundwater near the NuMI tunnel flows towards and into the tunnel as illustrated in Figure 4.2. Figure 4.2 shows a cross section of the NuMI tunnel within the layers of dolomite. The blue arrows represent the direction of water flow. Groundwater within 30 feet of the tunnel flows towards the tunnel [10]. 


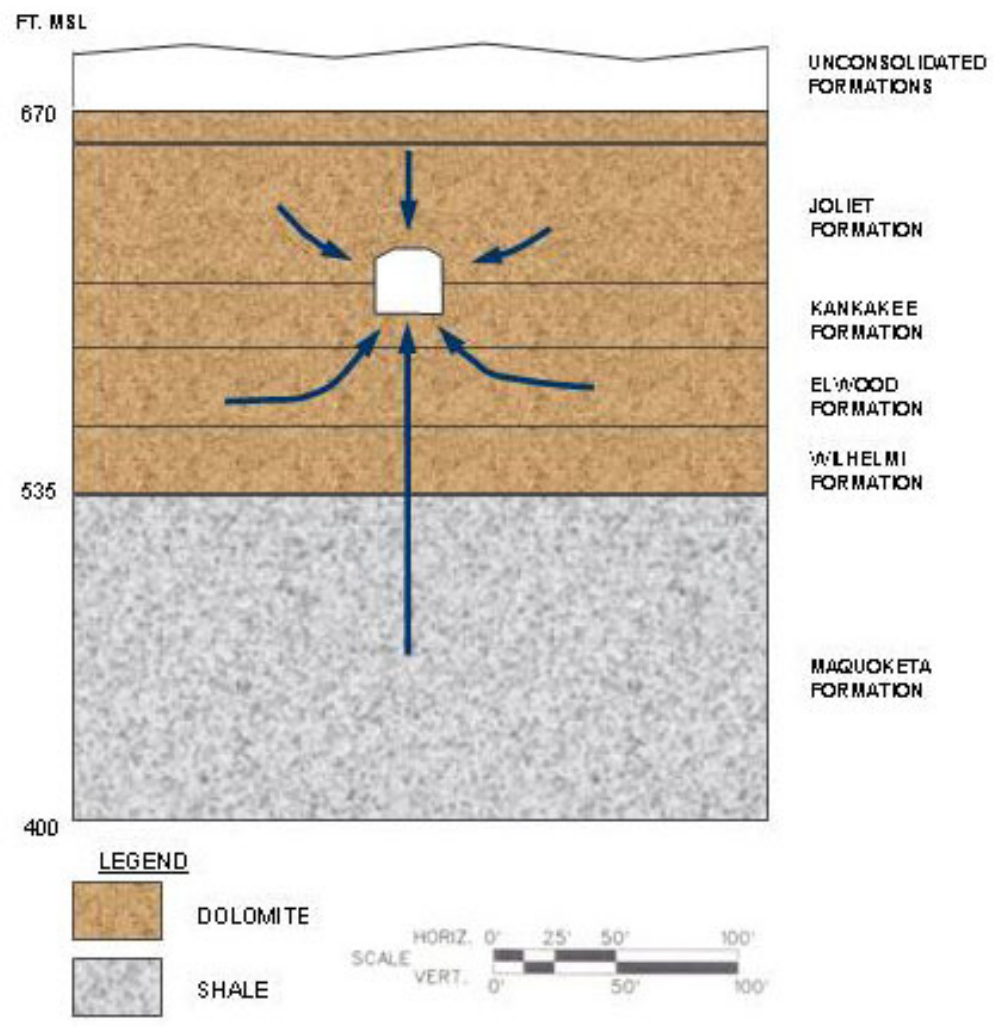

Figure 4.2: Diagram of Groundwater Flowing into the NuMI Tunnel.

The models have also provided estimates of groundwater inflow velocity [8] as illustrated in Figure 4.3. Figure 4.3 shows the layers of Glacial Till, Silurian Dolomite (Joliet, Kankakee, Elwood, and Wilhelmi Formations) and Makoqueta Group, along with a view of the NuMI tunnel. The color of the NuMI tunnel indicates the estimated inflow velocity of groundwater at the walls of the NuMI tunnel. The inflow velocity ranges from 0.01 to $10 \mathrm{feet} / \mathrm{day}$. The regions in the Silurian Dolomite layers have the fastest inflow rates. 


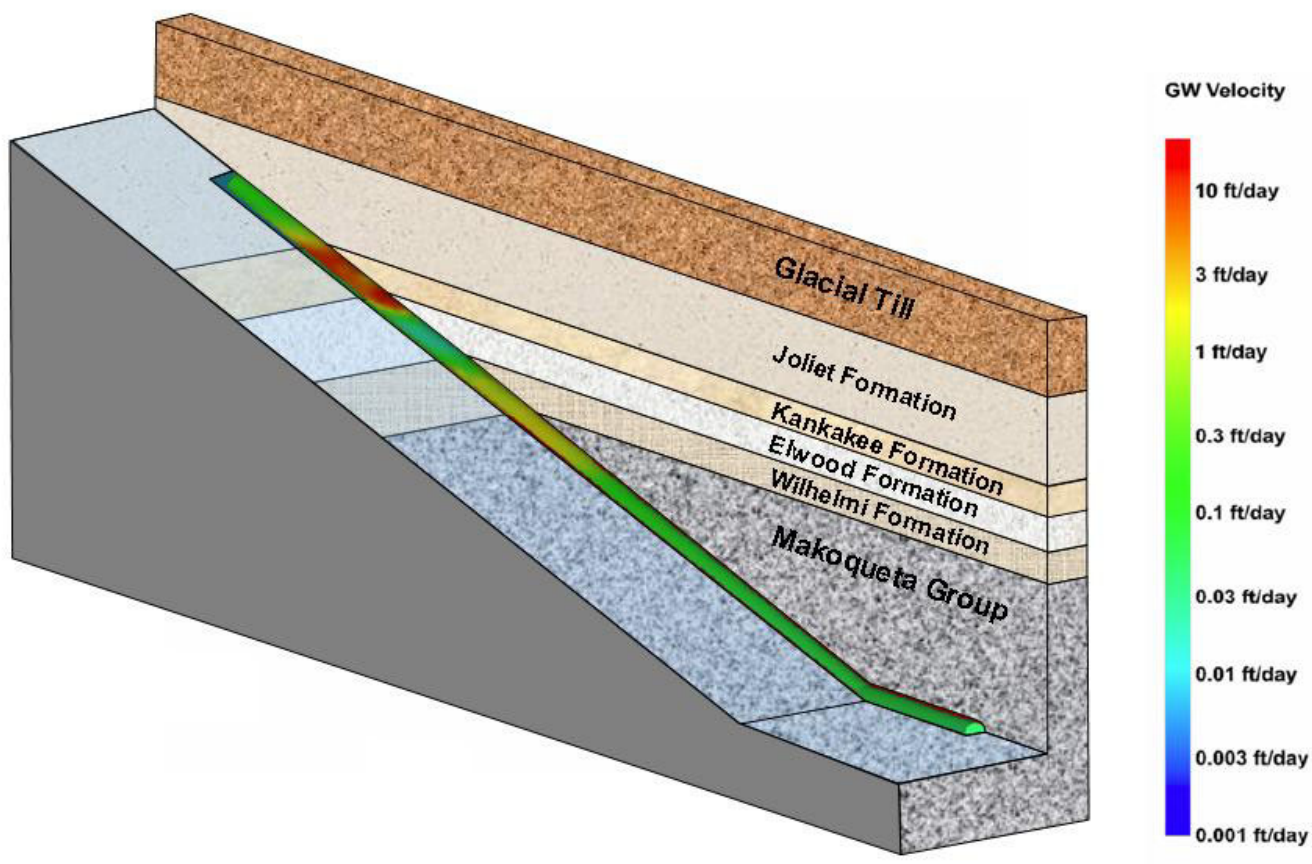

Figure 4.3: Modeled groundwater flow velocities into the NuMI tunnel. Shown is the NuMI tunnel within the geological layers. The color coding of the NuMI tunnel indicates the estimated groundwater velocity.

Water flowing into the NuMI tunnel enters a drainage system within the tunnel that leads to a sump pit at near the bottom of the tunnel. Water in the sump pit is pumped to the surface continuously and is used for replenishing the industrial cooling water (ICW) supply.

\subsection{Groundwater Protection}

Operating the NuMI beamline for the MINOS experiment produces radioactivity in the soil and rock surrounding the NuMI facility. As water passes through rock or soil containing radioactivity leaching contributes radioactivity to the water in the vicinity of the NuMI tunnel. Studies of the leachable radioactivity produced in soil and rock adjacent to NuMI tunnel show that the two principal radionuclides of concern are tritium and sodium-22 [12, 13].

Fermilab environmental policy [15] requires that activation levels of water from beamline operations remain below applicable regulatory limits. In the case of the Class I Silurian Dolomite, federal and state drinking water regulations apply [16, 17]. Adherence to these limits assures that anyone who would use water from the aquifer immediately outside of the tunnel as their primary source of drinking water on a full time basis would receive 
less than 40 microSieverts $(4 \mathrm{mrem})$ per year. Such direct usage of this source of water is exceedingly improbable.

The DOE standards for radionuclide concentrations in drinking (or potable) water are based on Derived Concentration Guides (DCGs) using the most conservative choices of GI tract absorption factor. The DCGs are documented in the Fermilab Radiological Control Manual (FRCM) [18]. The groundwater DCG for tritium is $20 \mathrm{pCi} / \mathrm{ml}$ and the groundwater DCG for sodium-22 is $0.4 \mathrm{pCi} / \mathrm{ml}$. In Illinois the tritium standard for a Class I groundwater (a potable resource water) is $20 \mathrm{pCi} / \mathrm{ml}$ [11]. To meet the requirements for drinking water the sum of the fractions of radionuclide concentrations, relative to the standards, must remain below $1 ; \mathrm{C}_{\mathrm{GW}}$, tritium $/ 20 \mathrm{pCi} / \mathrm{ml}+\mathrm{C}_{\mathrm{GW}}$, sodium-22 $/ 0.4 \mathrm{pCi} / \mathrm{ml}<1$, where $\mathrm{C}_{\mathrm{GW}}$, tritium and $\mathrm{C}_{\mathrm{GW}}$, sodium-22 are the concentrations of tritium and sodium-22 in the groundwater.

Water collected in the NuMI tunnel drainage system and pumped to the surface is considered surface water and is subject to DOE standards for surface water [16] as documented in the FRCM [18]. The surface water DCG for tritium $2,000 \mathrm{pCi} / \mathrm{ml}$ and the surface water DCG for sodium-22 is $10 \mathrm{pCi} / \mathrm{ml}$. To meet the requirements for surface water the sum of the fractions of radionuclide concentrations, relative to the standards, must remain below $1 ; \mathrm{C}_{\mathrm{SW}}$, tritium $/ 2,000 \mathrm{pCi} / \mathrm{ml}+\mathrm{C}_{\mathrm{SW} \text {, sodium-22 }} / 10 \mathrm{pCi} / \mathrm{ml}<1$, where $\mathrm{C}_{\mathrm{SW}}$, tritium and $\mathrm{C}_{\mathrm{SW}}$, sodium-22 are the concentrations of tritium and sodium-22 in the surface water. A person drinking water containing radioactivity at the DCG concentration for an entire year would receive a dose of $100 \mathrm{mrem}$.

The regulatory limits for tritium and sodium-22 concentrations in surface water and potable groundwater are summarized in Table 3. Verification that such limits are not exceeded is accomplished during the facility operation through the Fermilab monitoring program which is described in the Fermilab ES\&H Manual (FESHM) [15].

Table 3: Limits Applied to Concentrations of Accelerator Produced Radionuclides in Potable Groundwater Resources and Surface Waters at Fermilab.

\begin{tabular}{|c|c|c|}
\hline & Tritium & Sodium-22 \\
\hline Potable Groundwater & $20 \mathrm{pCi} / \mathrm{ml}$ & $0.4 \mathrm{pCi} / \mathrm{ml}$ \\
\hline Surface water & $2,000 \mathrm{pCi} / \mathrm{ml}$ & $10 \mathrm{pCi} / \mathrm{ml}$ \\
\hline
\end{tabular}

Standard computer modeling techniques have been used to calculate the potential radionuclide concentrations in groundwater resources adjacent to the NuMI facility. A methodology for determining radionuclide concentrations was developed and used to calculate radionuclide concentrations for running NuMI under the MINOS operating conditions $[23,24]$. The result was used to design the shielding for the NuMI facility that assures that radionuclide concentrations in the groundwater remain below drinking water standards specified in IEPA regulations for potable groundwater resources [11]. The tunnel containing the target station and the decay pipe is pumped continuously to assure that the inflowing water does not flood the tunnel. 
The estimated concentrations of tritium and sodium-22 in the groundwater have been calculated for NuMI operations at its design beam power of $400 \mathrm{~kW}$. The results are shown in Table 4 with the groundwater regulatory limits. The sum of estimated radionuclide concentrations, relative to the regulatory limits, is calculated to be 0.6 , a factor of almost 2 below the limits for drinking water. These estimated levels of activation only exist within 6 feet of the NuMI tunnel and the groundwater in this region flows into the NuMI tunnel. For approximately each 3 feet (90 centimeters) of additional rock, the concentrations decrease by a factor of 10. At distances of more than 6 feet from the NuMI tunnel the concentrations of radionuclides are negligible.

The same methodology has been used to estimate the radionuclide concentrations for NuMI operations at the NOvA beam powers. The result shows that the concentration of the radionuclides in the immediate vicinity of the tunnel would be above the IEPA standards for drinking water when NuMI would be operating at a beam power of $1.5 \mathrm{MW}$. However, this concentration of radionuclides would exist only within the first 6 feet of the NuMI tunnel wall. Furthermore, this water would be collected and discharged as described above to the Fermilab surface water pond system and ICW system. At distances of more than 6 feet from the NuMI tunnel the concentrations of radionuclides would be negligible, yet still well within the minimum capture zone of the flow of groundwater into the NuMI tunnel.

Table 4: Estimated radionuclide concentrations in the groundwater immediately outside of the NuMI tunnel that would be expected during the running of the NuMI facility under NOvA operating conditions.

\begin{tabular}{|c|c|c|}
\hline Type of Operations & $\begin{array}{c}\text { Estimated Maximum } \\
\text { Tritium Level }\end{array}$ & $\begin{array}{c}\text { Estimated Maximum } \\
\text { Sodium-22 Level }\end{array}$ \\
\hline NuMI/MINOS & $2 \mathrm{pCi} / \mathrm{ml}$ & $0.2 \mathrm{pCi} / \mathrm{ml}$ \\
\hline NuMI/NOvA & $7 \mathrm{pCi} / \mathrm{ml}$ & $0.7 \mathrm{pCi} / \mathrm{ml}$ \\
\hline $\begin{array}{c}\text { Groundwater } \\
\text { Regulatory Limits }\end{array}$ & $\mathbf{2 0} \mathbf{~ p C i} / \mathbf{m l}$ & $\mathbf{0 . 4} \mathbf{~ p C i} / \mathbf{m l}$ \\
\hline
\end{tabular}

The relative radionuclide production rate and water flow near the NuMI tunnel that would exist for NOvA operations are illustrated in Figure 4.4. The models and calculations for the radionuclide concentration are thoroughly documented in the NuMI Shielding Assessment Document (SAD) [2, 24, 33]. In the dolomite, the radionuclide production rate would decrease as one proceeds outward radially from the beamline through the rock. For approximately each 3 feet ( 90 centimeters) of additional rock, the concentration would decrease by a factor of 10. This is shown in Figure 4.4 where the height of the red shaded region shows what would be the relative production rates of radionuclides. The calculations show that $99 \%$ of all radionuclides that would be 
produced would be within the first 6 feet of the tunnel wall. Groundwater within a radius of 30 feet flows into the NuMI tunnel. At this distance, the concentration of radionuclides due to NuMI operations would be completely negligible.

Therefore, any radionuclides that would be produced in the water in the immediate vicinity of the NuMI tunnel would not flow away from the tunnel. The groundwater that would flow into the tunnel would be collected and continuously pumped to the surface where it would be considered surface water. This water would not be used as a drinking water supply.

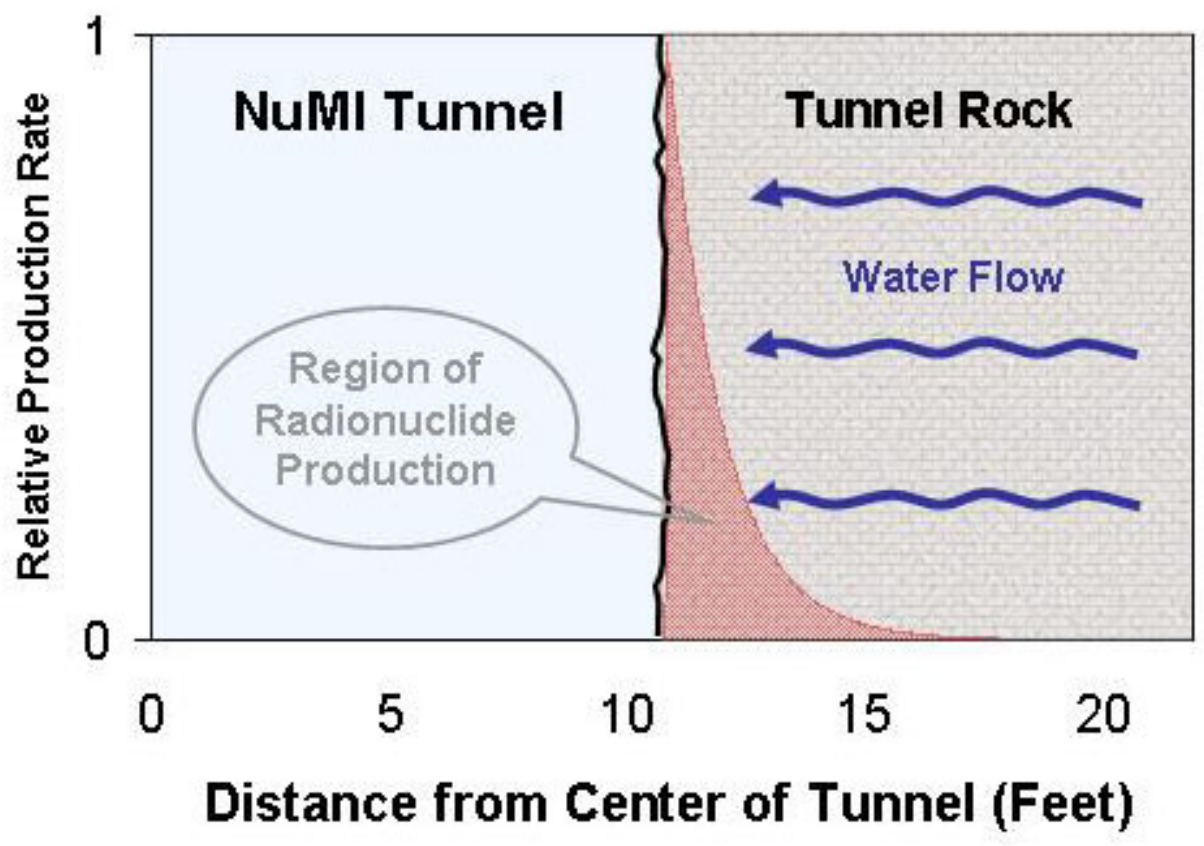

Figure 4.4: Illustration of the radionuclide production and water flow in the tunnel rock near the NuMI beamline.

Standard monitoring wells are located on the Fermilab site as part of a strategy to monitor the concentrations of radionuclides in the groundwater [14]. A standard monitoring well specifically designed and constructed for that purpose has been installed near the NuMI tunnel. Its placement was chosen to be at a location where the levels of activation of the rock surrounding the tunnel likely would be the greatest and where there is the greatest likelihood of water movement away from the facility. Water from this well has not shown any measurable radionuclides concentrations. An individual using water at the detectable levels of $0.2 \mathrm{pCi} / \mathrm{ml}$ for tritium and $0.03 \mathrm{pCi} / \mathrm{ml}$ for sodium- 22 as the sole source of drinking water would receive less than 40 microSieverts $(4 \mathrm{mrem})$ per year. Such direct usage of this source of water would be exceedingly improbable.

The well would be regularly monitored for radionuclide concentrations. In the exceptionally unlikely event that during the course of NOvA operations radionuclide concentrations are detectable at levels that could threaten the exceedance of drinking 
water standards, the proton beam intensity would be reduced until mitigating steps could be taken.

\section{Surface Water}

The Fermilab site is relatively flat as a result of past glacial action. The highest area, with an elevation of $244 \mathrm{~m}(800 \mathrm{ft})$ above mean sea level is near the northwestern corner. The lowest point, $218 \mathrm{~m}(715 \mathrm{ft})$ above mean sea level is toward the southeast. There are three watersheds that collect water on site. Surface water on the Fermilab site is retained in ponds and is moved across watersheds for use in the ICW system. Surface water runoff in the southeast is into Ferry Creek. The northern part of the site drains to Kress Creek. These two creeks drain to the West Branch of the DuPage River. Surface drainage in the west and southwest is to Indian Creek and the Fox River.

There is an inward flow of water toward the NuMI tunnel from the surrounding dolomite of about 170 gallons (650 liters) per minute that is collected and pumped to the surface where it is introduced into the ICW system. The water pumped from the NuMI tunnel can be radioactive with the radionuclides of primary concern being tritium and sodium- 22 . The hazard associated with the surface waters is ranked by comparing the concentration with the DCG values as shown in Table 3.

Since the initiation of experiments in the NuMI facility, several steps have been taken to reduce the amount of tritium in the water discharged from the NuMI tunnel. One step involves collecting condensate from the air chiller coils in the target hall into a collection tank. The water from the collection tank is periodically collected in barrels for processing and shipment to radioactive waste disposal facilities. Another mitigation step was the installation of desiccant units in the NuMI target hall to separate the humid (tritiated) air from the short lived radionuclides and send the tritium up air vents to the surface as air emissions. These mitigation steps resulted in a reduction of the tritium levels in the water pumped from the NuMI tunnel by a factor of about 7 .

During recent running of NuMI at a beam power level of $300 \mathrm{~kW}$, and after the implementation of the mitigation steps described above, the level of tritium in the sump water was measured to range between 5 and $8 \mathrm{pCi} / \mathrm{ml}$. The same sump water was analyzed for sodium-22 and showed no measurable sodium-22 at the detection limit of $0.03 \mathrm{pCi} / \mathrm{ml}$. Using these measurements and scaling the values relative to the total number of protons delivered to NuMI (a conservative scaling) allows for predictions of the levels of tritium and sodium-22 in the NuMI sump water during the approved running period of NuMI for MINOS operations. These conservative estimates predict that the tritium concentration in the NuMI sump water will remain in the range of 25 to $50 \mathrm{pCi} / \mathrm{ml}$ and the sodium-22 levels will remain below $0.27 \mathrm{pCi} / \mathrm{ml}$.

The most significant source of tritium in the pond water is from the NuMI tunnel. This water is analyzed weekly to determine the concentration of accelerator-produced radionuclides. The flow of surface water and the concentration of radionuclides have 
been modeled for the Fermilab site [21]. The model predicts a maximum tritium concentration in the range of 6 to $13 \mathrm{pCi} / \mathrm{ml}$ and a maximum sodium- 22 concentration of $0.07 \mathrm{pCi} / \mathrm{ml}$ during the approved running for MINOS operations. The measured and estimated concentrations for tritium and sodium- 22 are summarized in Table 5 and Table 6. All of the estimated concentrations are below the regulatory limit for surface water. The estimates for the pond water concentration are conservative because they assume drought conditions. In drought conditions the volume of water in the Fermilab pond system is reduced resulting in a higher concentration of radionuclides. The concentrations are estimated to be lower under non-drought conditions.

The design of the NuMI tunnel ensures that groundwater in its vicinity continuously flows into the tunnel, where it is collected and continuously pumped to the surface cooling ponds.

The estimated concentrations of tritium and sodium-22 in the surface water during the running of NuMI under operating conditions for NOvA would be higher than the concentrations for MINOS operations due to the higher beam power on target (1.5 MW of beam power for the NOvA experiment versus $400 \mathrm{~kW}$ for the MINOS experiment.) Conservative estimates of the tritium and sodium-22 concentration that would result from running NuMI under the NOvA operating conditions are summarized in Table 5 and Table 6. All of these concentrations would be below the regulatory limit for surface water.

Table 5: Measured concentrations of tritium in the NuMI sump and Fermilab ponds during present operations and the estimated maximum concentration levels during NuMI operations for the MINOS experiment and for the NOvA experiment.

\begin{tabular}{|c|c|c|c|}
\hline Phase & Total Protons & $\begin{array}{c}\text { Tritium Levels } \\
\text { (NuMI Sump Water) }\end{array}$ & $\begin{array}{c}\text { Tritium Levels } \\
\text { (Pond Water) }\end{array}$ \\
\hline $\begin{array}{c}\text { NuMI/MINOS } \\
\text { Present operations }\end{array}$ & $2 \times 10^{20}$ & $6 \mathrm{pCi} / \mathrm{ml}$ & $1 \mathrm{pCi} / \mathrm{ml}$ \\
\hline NuMI/MINOS & $18 \times 10^{20}$ & $25-50 \mathrm{pCi} / \mathrm{ml}$ & $6-13 \mathrm{pCi} / \mathrm{ml}$ \\
\hline NuMI/NOvA & $78 \times 10^{20}$ & $100-200 \mathrm{pCi} / \mathrm{ml}$ & $25-50 \mathrm{pCi} / \mathrm{ml}$ \\
\hline
\end{tabular}

Table 6: Measured concentrations of sodium-22 in the NuMI sump and Fermilab ponds during present operations and the estimated maximum concentration levels during NuMI operations for the MINOS experiment and for the NOvA experiment.

\begin{tabular}{|c|c|c|c|}
\hline Phase & Total Protons & $\begin{array}{c}\text { Sodium-22 Levels } \\
\text { (NuMI Sump Water) }\end{array}$ & $\begin{array}{c}\text { Sodium Levels } \\
\text { (Pond Water) }\end{array}$ \\
\hline $\begin{array}{c}\text { NuMI/MINOS } \\
\text { Present operations }\end{array}$ & $2 \times 10^{20}$ & $<0.03 \mathrm{pCi} / \mathrm{ml}$ & $<0.01 \mathrm{pCi} / \mathrm{ml}$ \\
\hline
\end{tabular}




\begin{tabular}{|c|c|c|c|}
\hline NuMI/MINOS & $18 \times 10^{20}$ & $<0.027 \mathrm{pCi} / \mathrm{ml}$ & $<0.07 \mathrm{pCi} / \mathrm{ml}$ \\
\hline NuMI/NOvA & $78 \times 10^{20}$ & $<1.2 \mathrm{pCi} / \mathrm{ml}$ & $<0.3 \mathrm{pCi} / \mathrm{ml}$ \\
\hline
\end{tabular}

\section{References}

1 D. Bogert, "NuMI-MINOS Status Report", Fermilab All Experimenter's Meeting, February 19, 2007. www-numi.fnal.gov/MinosAEM/presentations/AEM_19Feb2007.pdf

2 N. L. Grossman, "NuMI Beam Line \& MINOS Hall Shielding Assessment", September 4, 2004.

3 Illinois Environmental Protection Agency, Lifetime Operating Permit - National Emissions Standards for Hazardous Air Pollutants (NESHAP), Issued March 2, 2006, and application number 79070012, dated March 1, 1991.

4 K. Vaziri, "Radioactive Air Emissions Estimates from SNuMI Stacks", Memo dated October 12, 2006.

5 Title 40, Code of Federal Regulations, Part 61, Subpart H, "National Emission Standards for Emissions of Radionuclides Other Than Radon From Department of Energy Facilities".

6 RUST, "NS1 and NS2 Hydrogeologic Site Characterization and Well Installations and Aquifer Pumping Test Report", Fermi National Accelerator Laboratory, Batavia, Illinois, 1996.

7 STS Consultants, Ltd., "Hydrogeological Evaluation Report, Neutrino Main Injector (NuMI) Project, Fermi National Accelerator Laboratory, Batavia, IL, STS Project No. 12050-DL", 1997.

8 F. Breen, "Evaluation of Boundary Conditions for the Two Dimensional Groundwater Simulations”, Technical Memorandum, June 12, 1999.

9 Breen GeoScience Inc., "NuMI 3D Groundwater Model Update”, August 2004.

10 Earth Tech, Inc. "Two-Dimensional Groundwater Flow Model Results. Estimated Inflow to NuMI Tunnel”, May 1999.

1135 Illinois Administrative Code Part 620.410(e)(3), "Groundwater Quality Standards". 
12 T. B. Borak, et. al., "The Underground Migration of Radionuclides Produced in Soil Near High Energy Proton Accelerators", Health Physics 23, pp. 679-687, November 1972.

13 S. Baker, J. Bull, and D. Goss, "Leaching of Accelerator-Produced Radionuclides", Superconducting Super Collider Laboratory, Report SSCLPreprint-538, May, 1994.

14 P. Kesich, J. D. Cossairt, "The Groundwater Monitoring Strategy for NuMI", NuMI-Note-Beam-967, December 2003, ES\&H Section, Environmental Protection Team, Environmental Protection Procedures Manual, Procedures 100, 105, 109.

15 "Fermilab Environment, Safety, and Health Manual", This document contains Fermilab's policies for assuring worker safety and protection of the public and environment in accordance with Federal, State, and Local Regulations and good management practices.

16 U. S. Department of Energy Order 5400.5, "Radiation Protection of the Public and the Environment".

17 Title 40, Code of Federal Regulations, Part 141, "National Primary Drinking Water Regulations".

18 "Fermilab Radiological Control Manual". This document contains Fermilab's policies for assuring worker safety and protection of the public and the environment from sources of ionizing radiation. It is part of the Fermilab Environment, Safety, and Health Manual.

19 National Council on Radiation Protection and Measurements Report 94, "Exposure of the Population in the United States and Canada from Natural Background Radiation", Washington, DC, 1987.

20 Title 40, Code of Federal Regulations, Part 61, Subpart H, "National Emission Standards for Emissions of Radionuclides Other Than Radon From Department of Energy Facilities".

21 J. Donald Cossairt, "A Model for Calculating Radionuclide Concentrations in Fermilab Cooling Ponds", Fermilab Environmental Protection Note No. 25, June 2006.

22 “Fermilab Environmental Management System".

23 N. Grossman, R. Rameika, "Methodology for Determining Radionuclide Concentration in Groundwater in the Vicinity of Accelerator and Beamline Enclosures", NuMI-Note-Beam-0970, July 2004. 
24 N. Grossman, "Radionuclide Concentration in Groundwater in the Vicinity of NuMI Beamline Enclosures", NuMI-Note-Beam-1020, August 2004.

25 Illinois Environmental Protection Agency, NPDES Permit Number IL0026123, Issued on 12/21/99.

26 Illinois Environmental Protection Agency, NPDES Pretreatment Permit Number 005-EP-4233 Issued on 8/05/05.

27 Title 10, Code of Federal Regulations, Part 851.

28 National Fire Protection Administration. "National Fire Codes" (NFPA Standards).

29 Title 10, Code of Federal Regulations, Part 835.

30 N.V. Mokhov, "The MARS Code System User's Guide", Fermilab-FN-628 (1995); N.V. Mokhov, O.E. Krivosheev, "MARS Code Status", Proc. Monte Carlo 2000 Conf., p. 943, Lisbon, October 23-26, 2000; Fermilab-Conf-00/181 (2000); N.V. Mokhov, "Status of MARS Code", Fermilab-Conf-03/053 (2003);

31 J. D. Cossairt, N. L. Grossman, E. T. Marshall, "Assessment of Dose Equivalent Due to Neutrinos", Health Physics, Volume 73, Number 6, pp. 894-898, 1997. (Also Fermi National Accelerator Laboratory, Fermilab Report FERMILAB-Pub-97/101, April, 1997.)

32 D. A. Crane, et al., "Status Report: Technical Design of Neutrino Beams for the Main Injector (NuMI)", Fermi National Accelerator Laboratory, Report FERMILAB-TM-1946, July, 21, 1995.

33 B Lundberg, "NuMI Secondary Beam MARS Modeling”, NuMI-Note-Sim-1010, August 2004.

34 J. D. Cossairt, "Options and Considerations in the Decontamination and Decommissioning of the Neutrinos at the Main Injector (NuMI) Beamline", Fermilab EP Note No. 26, December 2006. 